\title{
Effects of the Novel NMDA Receptor Antagonist Gacyclidine on Recovery from Medial Frontal Cortex Contusion Injury in Rats
}

\author{
Jeffrey S. Smith ${ }^{2}$, Zoltan L. Fulop ${ }^{1}$, Steven A. Levinsohn, Richard S. Darrell ${ }^{1}$, and Donald G. Stein ${ }^{1,2 \dagger}$ \\ Departments of Neurology ${ }^{l}$ and Psychology, ${ }^{2}$ Emory University, Atlanta, GA 30322
}

\begin{abstract}
Gacyclidine, a novel, noncompetitive NMDA receptor antagonist, was injected (i.v.) into rats at three different doses to determine if the drug could promote behavioral recovery and reduce the behavioral and anatomical impairments that occur after bilateral contusions of the medial frontal cortex (MFC). In the Morris water maze, contused rats treated with gacyclidine at a dosage of $0.1 \mathrm{mg} / \mathrm{kg}$ performed better than their vehicle-treated conspecifics. Rats given gacyclidine at either 0.3 or $0.03 \mathrm{mg} / \mathrm{kg}$ performed better than brain-injured controls, but not as well as those treated with $0.1 \mathrm{mg} / \mathrm{kg}$. Counts of surviving neurons in the nucleus basalis magnocellularis (NBM) and the medial dorsal nucleus (MDN) of the thalamus were used to determine whether gacyclidine treatment attenuated secondary cell death. In both the NBM and the MDN, the counts revealed fewer surviving neurons in untreated contused rats than in gacyclidine-treated rats. Increases in the size and number of microglia and astrocytes were observed in the striatum of gacyclidinetreated contused brains. Although most consequences of MFC contusions were attenuated, we still observed increases in ventricle dilation and thinning of the cortex.
\end{abstract}

\footnotetext{
${ }^{\dagger}$ Corresponding author:

The Brain Research Laboratory, Emory University

575 Rollins Way, Atlanta, GA 30322

phone: +1-(404) 727-6034; fax: +1-(404) 727-2388

Email: dgstein@gsas.emory.edu
}

In fact, the ventricles of rats treated with 0.1 $\mathrm{mg} / \mathrm{kg}$ of gacyclidine were larger than those of their vehicle treated counterparts, although we observed no behavioral impairment.

\section{KEYWORDS}

gacyclidine, contusion, medial frontal cortex, trauma, Morris water maze, recovery of function, inflammation, NMDA-receptor antagonist

\section{INTRODUCTION}

Following traumatic brain injury, excitatory amino acids, such as glutamate, increase to toxic levels and may cause further damage to compromised neurons in the injury zone and to more distal nerve cells (Murphy \& Pearce, 1987; McIntosh, 1994; Myseros \& Bullock, 1995). Glutamate, binding to the glutamate recognition site of the NMDA receptor-ionophore complex, permits sodium and calcium ions to enter into the neuron, and if in excess, can initiate hyperexcitation, cytotoxic edema, and eventually cell death (Faden et al., 1989). Agents that block any of the specific recognition sites of the NMDA receptor-ionophore complex (NMDA antagonists) or the binding sites within the channel (noncompetitive NMDA antagonists) will attenuate calcium influx (Bullock \& Fujisawa, 1992; Bullock, 1995) and increase the likelihood of neuronal survival.

Several different types of NMDA receptor antagonists, such as phencyclidine (PCP), thienyl 
phencyclidine (TCP), and dizocilpine maleate (MK-801), have been shown to enhance functional recovery and promote neuronal sparing after different forms of central nervous system (CNS) injury (Panter \& Faden, 1992; Golding \& Vink, 1995; Okiyama et. al., 1997). Some of these agents, however, have been shown to produce negative side effects, such as hallucinations and neuronal vacuolization (Olney et al., 1991; Muir \& Lees, 1995).

A novel, noncompetitive NMDA antagonist, gacyclidine [GK-11; (cis (Pip/Me 1-[(1-2-thienyl)2-methylcyclohexyl] piperidine)], recently developed by Beaufour Ipsen Pharmaceuticals (France), is a molecule that is structurally derived from TCP. Gacyclidine is very selective for the PCP binding site within the NMDA receptor ion channels, having a binding rate 2.2 and 8.6 times higher than that of TCP and PCP, respectively (Drian et al., 1991). In vitro, gacyclidine has been shown to be protective against acute glutamate toxicity to neurons of the cortex, hippocampus, and spinal cord (ibid.). In this study, we evaluated the effectiveness of gacyclidine in reducing the behavioral and histopathological consequences of experimentally induced traumatic brain injury in adult male rats. We created contusions of the medial frontal cortex because this injury model simulates the type of head trauma often seen in humans (Mattson \& Levin, 1990). In this model, the loss of neurons expressing NMDA receptors is associated with impaired learning and memory (Hoffman et. al., 1994) following traumatic brain injury. Bilateral damage to the medial frontal cortex in rats induces persistent deficits in cognitive and sensorimotor performance. We have chosen to use the Morris water maze (MWM) because in repeated experiments, this task has been shown to be particularly sensitive to lesions of the frontal cortex (Kolb et al., 1982; Hoffman et al., 1994; Lindner et al., 1998). We believe that the MWM can be used to measure both working and/or reference memory, but in our task we were primarily concerned with enhancing performance in brain damaged animals rather than in the specific nature of the task itself. The deficits observed in the MWM following MFC contusions are persistent and amenable to manipulation by drugs and by other procedures we have used in previous work (Stein et al., 1991; Attella et al., 1992; Roof et al., 1994; Janis et al., 1998). Because treatment with gacyclidine protects against glutamate toxicity in vitro, we reasoned that systemic administration of the drug might effect gliosis, prevent secondary neuronal death, and help reduce the behavioral deficits in the MWM that are seen after medial frontal cortex contusions.

\section{MATERIALS AND METHODS}

\section{Subjects}

Sixty-four male Sprague-Dawley rats $(\sim 90$ days old), weighing from 320 to 380 grams each at the time of injury, were used. The animals were housed individually in hanging stainlesssteel cages, with a 12:12 hour reversed light cycle (8:00 to 20:00, dark period, 20:00 to 8:00, light period), and allowed ad libitum access to rat chow and water. Each rat was weighed and handled for $5 \mathrm{~min} / \mathrm{d}$ during the week before and the week after the surgery.

\section{Surgery}

All rats were food deprived for $24 \mathrm{~h}$ before surgery. The rats were injected (i.p.) with $0.05 \mathrm{ml}$ atropine sulfate (to reduce respiratory congestion), anesthetized with sodium pentobarbital (Nembutal, $50 \mathrm{mg} / \mathrm{kg}$ ) and mounted in a stereo-taxic device. A midline incision was made in the scalp, the fascia was retracted, and the cranium was exposed, using aseptic technique. At this point, all sham-operated controls were sutured and prepared for the injection of gacyclidine or vehicle (sterile water). Details of the contusion procedure have been reported previously (Hoffman et. al., 1994), but will be briefly 
outlined here. The rats that were destined to receive cortical contusions of the medial frontal cortex first underwent a 6-mm-diameter craniotomy (centered at $3.0 \mathrm{~mm}$ anterior to bregma). After removal of the bone, the tip of the impactor was moved to AP: 3.0; ML: 0.0 (Paxinos \& Watson, 1982), checked for adequate clearance, retracted to its elevated position, and then lowered $3.5 \mathrm{~mm}$ DV so that it would penetrate the cortex $2 \mathrm{~mm}$. The impact velocity was $2.25 \mathrm{~m} / \mathrm{sec}$ with a $0.5-\mathrm{sec}$ duration before retraction. Hemorrhaging was stopped (by applying cold saline-soaked gelfoam sponges) before closure of the incision. Immediately after surgery, the rats' tails were placed in warm $\left(40^{\circ} \mathrm{C}\right)$ water to induce vasodilation to allow intravenous injection.

\section{Drug administration}

Ten minutes after the contusion, the rats received either gacyclidine or the vehicle (sterile water) in a single intravenous injection into the dorsal tail vein, at doses of either $0.3,0.1$, or 0.03 $\mathrm{mg} / \mathrm{kg}$. After the injections, the rats were placed in a warm, dry, well-ventilated cage and allowed to recover fully from the surgical procedure before being returned to the colony.

\section{Behavioral assessment}

Activity monitoring. The animals were placed in Omnitech ${ }^{\mathrm{TM}}$ activity monitoring boxes for 10 min each day. To determine the acute effect of the drug on activity of the rats, we measured this behavior on the first, third, and fifth days post injury. To test for any long lasting effect, we measured activity levels again on the twenty-first and twenty-fourth days post injury. The total amount of time spent moving was the dependent variable.

Morris water maze. After 7 days of postoperative recovery, the animals began training in the MWM (Morris, 1981, Hoffman et al., 1994). Each animal received 2 trials per day for 10 days, a total of 20 trials. The water maze consisted of a large, circular pool, $115 \mathrm{~cm}$ in diameter, filled with water made opaque by the addition of white, non-toxic paint. A submerged escape platform $(11 \times 11 \mathrm{~cm})$ was placed in the southeast corner of the tank, $1.5 \mathrm{~cm}$ under the water so that it could not be seen by the rats. A trial began by placing a rat into the water at one of four possible starting positions ( N, E, S, W) and ended when the animals located and climbed onto the escape platform or after $90 \mathrm{sec}$ had elapsed. If a rat could not locate the submerged platform within $90 \mathrm{sec}$, the experimenter would guide it to the escape location.

\section{Histological methods}

Preparation for light microscopy. When all behavioral tests were completed, the rats were given a lethal dose $(80 \mathrm{mg} / \mathrm{kg}$, i.p.) of Nembutal, followed by an intracardiac perfusion of $100 \mathrm{~mL}$ phosphate buffered saline (pH 7.4) and $500 \mathrm{~mL}$ $4 \%$ paraformaldehyde (PAF) solution ( $\mathrm{pH} 7.4$ ). After perfusion, the brains were removed from the skull, post-fixed in $4 \% \mathrm{PAF}$, and then sequentially cryoprotected in $10 \%, 20 \%$, and $30 \%$ sucrose solutions $(\mathrm{pH} 7.4), 12 \mathrm{~h}$ in each. Three separate series of $40-\mu \mathrm{m}$-thick sections were cut on a freezing microtome and then immediately mounted on gelatin-coated slides in preparation for staining or placed into cyroprotectant (Watson et al., 1986) for later immunocytochemistry. The first series of sections, stained with thionin, were used for general morphological analyses (ventricular dilation, cortical thickness), and for neuronal counts; the second and third series were stained, using glial fibrillary acidic protein (GFAP) immunocytochemistry for astrocytes and silver impregnation for microglia.

GFAP immunocytochemistry: To visualize the presence of reactive astrocytes, $40-\mu \mathrm{m}$-thick free-floating sections were immunolabeled using the peroxidase-antiperoxidase method described in detail elsewhere (Fulop et al., 1997). 
Gallyas silver staining for microglia. An additional series of $40-\mu \mathrm{m}$-thick sections were stained for activated microglial cells, using a silver impregnation method described by Gallyas (1970). This method effectively stains all types of activated microglial cells and any macrophages that are present within the CNS after trauma.

\section{Image analysis}

Anatomical analysis was aided by a video microscopy system. The images were captured using a single-chip, analog color video camera. Once captured and saved in tiff format on the PC, the image was cropped using Adobe Photo Shop ${ }^{\mathrm{TM}}$ and imported into UTHSCSA ImageTool (v. 1.27) for further quantitative morphometric assessment. All investigators were blind as to group assignment until the completion of the study.

Lesion reconstruction. Sections at three levels $(3.5,2.5,1.5 \mathrm{~mm})$ anterior to bregma were captured at a magnification of $1.67 \times$. The lesion cavity was traced and measured using the ImageTool software package. The area of the three levels of lesion cavities was quantified and summed to determine a mean area percentage. The scores were then used to compute a mean area ratio score (area of the lesion/area of lesion + total area of the slice). The ratios were then used to determine the differences, if any, in lesion cavity size between treatment levels.

Ventricle dilation was measured on thioninstained sections at the level of $1.0 \mathrm{~mm}$ anterior to bregma. The area of each ventricle was traced and quantified using the ImageTool software package. The area scores were used to compute a mean area ratio score (area of the ventricles/area of ventricles + total area of the slice). The ratios were used to calculate differences in ventricle size between lesion and treatment levels.

Cortical thickness. The thickness of the cortex (the radial distance between the outer surface of the cortex and the dorsal aspect of the corpus callosum) was measured at three points
$(1.0,2.5,4.5 \mathrm{~mm})$ from the midline. Both the right and the left hemisphere, at the level of 1.0 $\mathrm{mm}$ anterior to bregma from each brain, were examined. The six points were then summed to determine a mean cortical thickness for each animal. The mean areas were used to measure any differences in cortical thickness between the lesion and treatment levels.

Neuronal counts. Cholinergic neurons in the rat nucleus basalis magnocellularis (NBM), which account for $70 \%$ to $80 \%$ of neocortical cholinergic innervation, have been implicated in learning and memory (Dekker, et. al., 1991). Damage to the medial frontal cortex disrupts cholinergic innervation to the neocortex of the basal forebrain and can cause retrograde degeneration of neurons in the NBM (Gray \& McNaughton, 1983; Dekker et al., 1991). The medial dorsal nucleus of the thalamus (MDN) has also been shown to be a subcortical structure that projects to the prefrontal cortex (Leonard, 1969). As a measure of retrograde degeneration, images $(\times 40)$ were selected from within the NBM, at three different levels $(+0.01,+0.00,-0.01 \mathrm{~mm})$ to bregma and from the MDN $(-2.3,-2.8,-3.3$ $\mathrm{mm}$ ) were analyzed for neuronal-cell survival. In the NBM, the area $\left(507 \mu \mathrm{m}^{2}\right)$ where the counts were conducted was bordered dorsally by the anterior commisure, medially by the lateral preoptic area, ventrally by the nucleus of the diagonal band, and laterally by the fundus of the striatum.

In the MDN, the area $\left(507 \mu \mathrm{m}^{2}\right)$ where the counts were made was bordered dorsally by the lateral habenula, medially by the paraventricular thalamic area, ventrally by the central medial nucleus and by the paracentral nucleus of the thalamus, and laterally by the centrolateral nucleus of the thalamus (Paxinos \& Watson, 1986). With the assistance of ImageTool software, we counted all cells that we determined to be viable neurons, using the following criteria: (a) even staining of the nucleus, (b) no visible signs of swelling, and (c) containing definitive cell bodies and an observable nucleus. 
GFAP immunoreactive astrocytes and activated microglial cell counts. Sample areas, $507 \mu^{2}(\times 40)$, within the striatum, at three different levels $(+2.00,+0.10,-0.50 \mathrm{~mm})$, were selected to quantify astrocytes and microglial cells. The cells were counted, and then five randomly selected cells from each sample were traced (using ImageTool) to determine the surface area as a measure of cell size.

\section{Statistics}

Data were analyzed with the appropriate multi-way analysis of variance (ANOVA) or ANOVA for repeated measures with Tukey's post hoc ANOVA analysis of the results, using statistical software packages including SPSS ( $\mathrm{v}$. 8.0), SigmaSTAT (v. 1.0), and SigmaPLOT (v.4.0).

\section{RESULTS}

\section{Activity measurements}

Analyses of the activity levels of the rats were made on the first, third, and fifth postoperative days and again on the twenty-second and twenty-fourth postoperative days (Fig. 1). A two-way, repeated-measures ANOVA showed a significant effect of time, $\left[\mathrm{F}_{(4,216)}=12.84, \underline{p}<0.001\right]$, and an interaction between time and lesion, $\left[\mathrm{F}_{(4,216)}=\right.$ $16.68, \mathrm{p}<0.001]$. Tukey's post hoc analysis revealed that on the first postoperative day, rats given medial frontal cortex lesions were less active than intact controls. On the third postoperative day, the activity increased (toward normal levels) and then declined on the fifth postoperative day. After MWM training, the activity levels of the rats
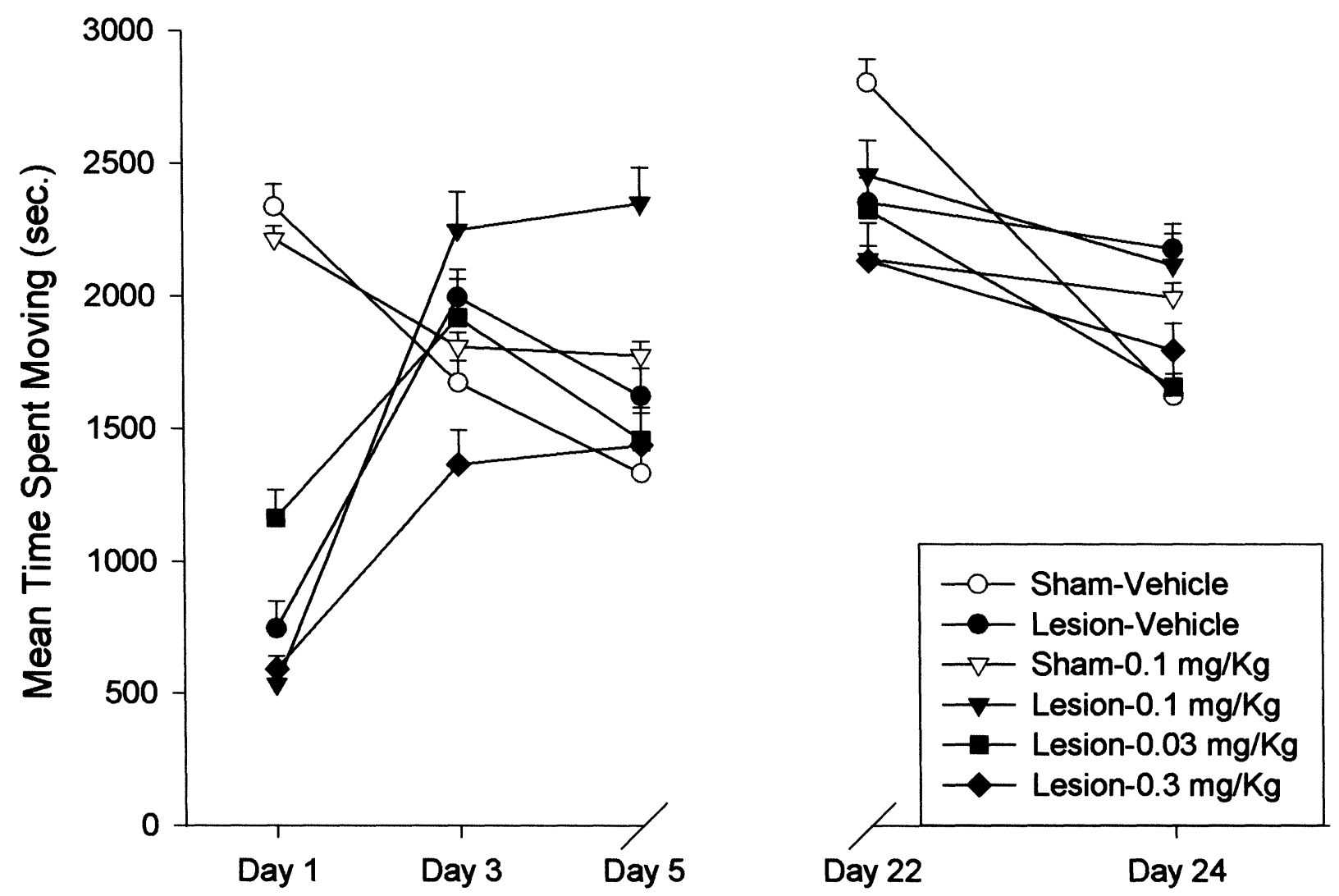

Fig. 1: Analysis of the activity levels of the rats were conducted on the first, third, and fifth postoperative day and again on the twenty-second and twenty-fourth postoperative day. A significant effect of time and an interaction between time and lesion $(\mathrm{p}<0.05)$ can be seen. 
were re-examined to determine any residual effects of gacyclidine treatment. No difference among the drug treatment groups was noted.

\section{Morris water maze}

Measures of swim time in the water tank before finding the escape platform revealed a significant lesion effect $\left[F_{(1,56)}=96.52, p<0.001\right]$, a significant drug effect, $\left[\mathrm{F}_{(3,56)}=6.37, \mathrm{p}<0.05\right]$, a lesion $\times$ day interaction, $\left[\mathrm{F}_{(9,504)}=4.07, \mathrm{p}<0.001\right]$, and a lesion $\times$ drug $\times$ day interaction $[F(27,504)=1.94$, $\mathrm{p}<0.05$ ].

The animals treated with $0.1 \mathrm{mg} / \mathrm{kg}$ of gacyclidine performed significantly better than the lesion-vehicle group, both early and late in training. This analysis showed that regardless of dose, the drug improved the performance of the injured rats (Fig. 2a). Additionally, injured rats given $0.1 \mathrm{mg} / \mathrm{kg}$ of gacyclidine performed
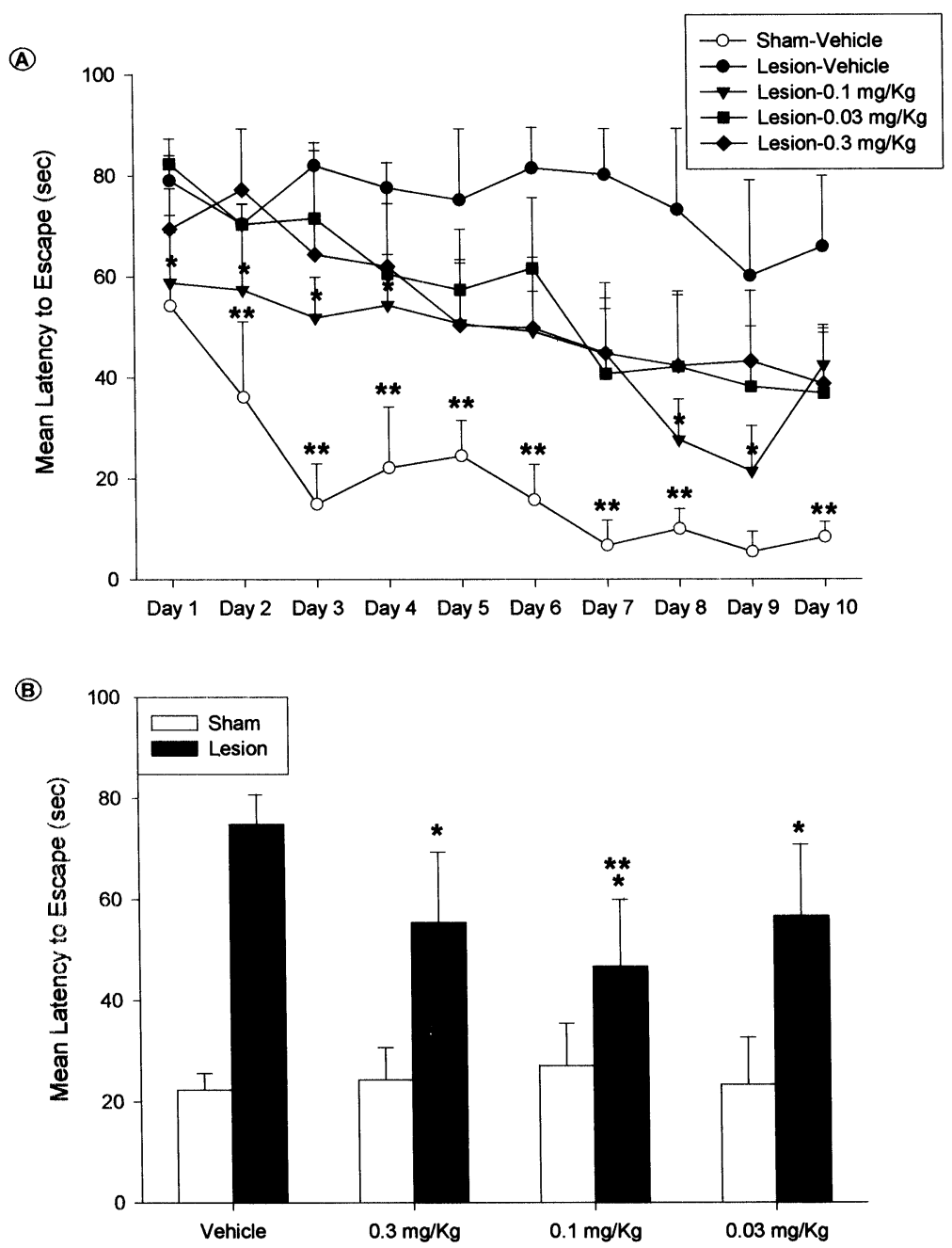

Fig. 2: (a) Measures of swim time in the water tank before finding the escape platform show that rats given 0.1 $\mathrm{mg} / \mathrm{kg}$ of gacyclidine performed better than the other treatment groups, both early and late in training $(*=p<0.05)$. Regardless of dose, intact rats performed significantly better than any of the three gacyclidine groups $(* *=p<0.05)$, except on day 8 , when the $0.1 \mathrm{mg} / \mathrm{kg}$ group was not significantly different from the intact controls. (b) Collapsing the data across days revealed that injured rats receiving $0.1 \mathrm{mg} / \mathrm{kg}$ performed better than those receiving either of the other two doses $(* *=p<0.05)$. All injured rats receiving gacyclidine, regardless of dose, performed better than their untreated counterparts $\left({ }^{*}=p<0.05\right)$. (Error bars represent SD). 
significantly better $(\underline{p}<0.05)$ than those receiving either of the other two doses. The gacyclidine treated animals did not reach performance levels equivalent to those of intact controls. The latency measure (Fig. 2a) revealed a significant drug effect throughout the duration of testing, with all doses of the drug producing shorter swim latencies than those found in the vehicle treated counterparts. When the data were summed across days, a 2-way ANOVA produced a significant main effect of lesion $\left[F_{(1,56)}=95.40, \underline{p}<0.001\right]$ and a significant interaction of drug $\times$ lesion $\left[\mathrm{F}_{(3,56)}=\right.$ 3.79, p $<0.05$ ] (Fig. 2b).

Comparison of the distance traversed by the rats while searching for the escape platform also revealed a significant lesion effect, $\left[F_{(1,56)}=78.02\right.$, $\mathrm{p}<0.001]$, a significant lesion $\times$ drug interaction, $\left[\mathrm{F}_{(3,56)}=3.72, \underline{\mathrm{p}}<0.05\right]$, a lesion $\times$ day interaction, $\left[\mathrm{F}_{(9,504)}=4.32, \mathrm{p}<0.001\right]$, and a drug $\times$ day interaction, $\left[\mathrm{F}_{(27,504)}=1.71, \mathrm{p}<0.05\right]$ (Fig. 3). When comparing the distance traveled by the rats, we found that the performance of gacyclidinetreated rats was significantly better than that of rats in the lesion-vehicle group by the final three days of testing $(\mathrm{p}<0.05)$, although no treatment group reached the level of performance of intact rats. On the second, eighth, and tenth days of training, rats treated with $0.1 \mathrm{mg} / \mathrm{kg}$ of gacyclidine performed better than those in the other treatment groups (Fig. 3a). When the data were summed across days, a 2-way ANOVA produced a significant main effect of lesion $\left[\mathrm{F}_{(1,56)}=77.40, \mathrm{p}<0.001\right]$ and a significant interaction of drug $\times$ lesion $\left[\mathrm{F}_{(3,56)}=3.69, \mathrm{p}<0.05\right]$ (Fig. $3 b)$.

\section{Ventricular dilation}

Figure $4 \mathrm{a}$ shows that the ventricles of rats treated with $0.1 \mathrm{mg} / \mathrm{kg}$ of gacyclidine were significantly larger $\left[\mathrm{F}_{(3,39)}=21.05, \mathrm{p}<0.001\right]$ than those of vehicle-treated animals with similar lesions. A small but nonsignificant ventricular enlargement was noted in sham-operated rats given a dose of $0.3 \mathrm{mg} / \mathrm{kg}$ of gacyclidine.

\section{Cortical thickness measurements}

In addition to ventricular dilation, rats receiving the $0.1 \mathrm{mg} / \mathrm{kg}$ dose of gacyclidine also showed a significant decrease in cortical thickness, measured at three locations, in comparison with contused rats given only vehicle injections $\left[\mathrm{F}_{(3,256)}=5.574, \quad \mathrm{p}=0.001\right]$. Further analysis using Tukey's post hoc comparisons showed that rats treated with the $0.1 \mathrm{mg} / \mathrm{kg}$ dose of gacyclidine had the thinnest cortex of the three doses (Fig. 4b). It is also interesting to note that animals given the $0.1 \mathrm{mg} / \mathrm{kg}$ dose showed the best behavioral recovery when compared with rats given lower doses of gacyclidine. Sham-operated controls, regardless of dose, showed no changes in cortical thickness.

\section{Lesion reconstruction}

To determine lesion size and location, we performed lesion reconstruction (Fig. 5) and compared animals treated with $0.03,0.1$, and 0.3 $\mathrm{mg} / \mathrm{kg}$ doses of gacyclidine with vehicle-treated animals and surgical controls. Among the three treatment groups, no difference was found in the size of the lesions ( $p>0.05$ for all). Additionally, lesion reconstruction showed that the contusion injuries were about the same size and symmetrical.

Neuronal counts in the nucleus basalis magnocellularis (NBM)

Regardless of treatment conditions, the number of surviving neurons in the nucleus basalis showed a decline in all animals with cortical contusions $\left[\mathrm{F}_{(1,20)}=34.67, \underline{\mathrm{p}}<0.001\right]$ when compared with their non-contused counterparts. Our analysis indicated, however, that rats treated with $0.1 \mathrm{mg} / \mathrm{kg}$ of gacyclidine had more surviving neurons than their vehicle treated 

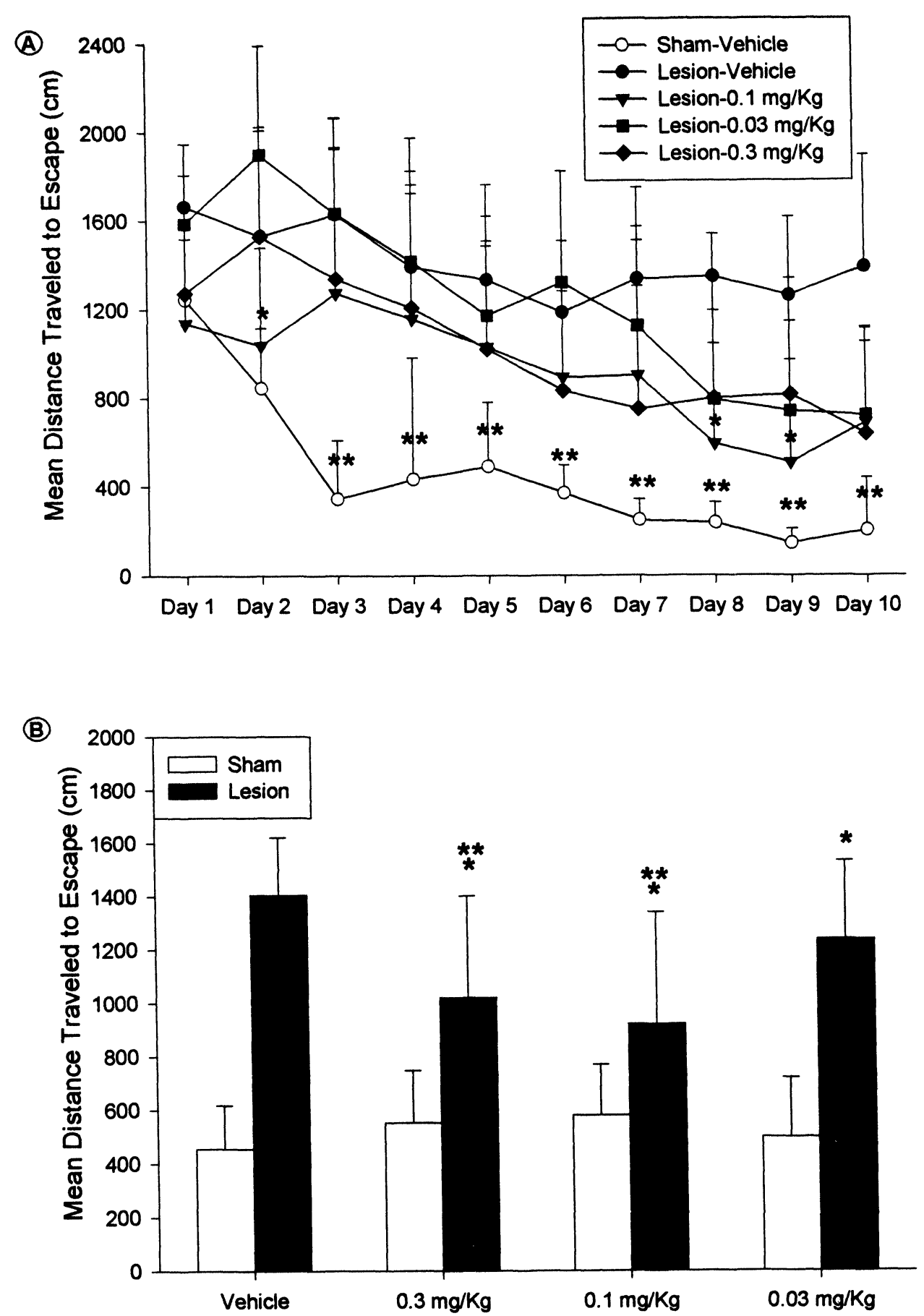

Fig. 3: (a) Measures of swim distance in the water tank before finding the escape platform shows that on the second, eighth, and ninth day of training, rats given $0.1 \mathrm{mg} / \mathrm{kg}$ of gacyclidine performed better than the other treatment groups $(*=p<0.05)$. Regardless of dose, intact rats performed significantly better than any gacyclidine-treated group $(* *=p<0.05)$. (b) When collapsed across days, the data revealed that injured rats treated with the two higher doses of gacyclidine performed better than those treated with $0.03 \mathrm{mg} / \mathrm{kg}$ of gacyclidine or with the vehicle $(* *=p<0.05)$. All injured rats receiving gacyclidine, regardless of dose, performed better than their untreated counterparts $(*=p<0.05)$. (Error bars represent standard deviation). 
(A)

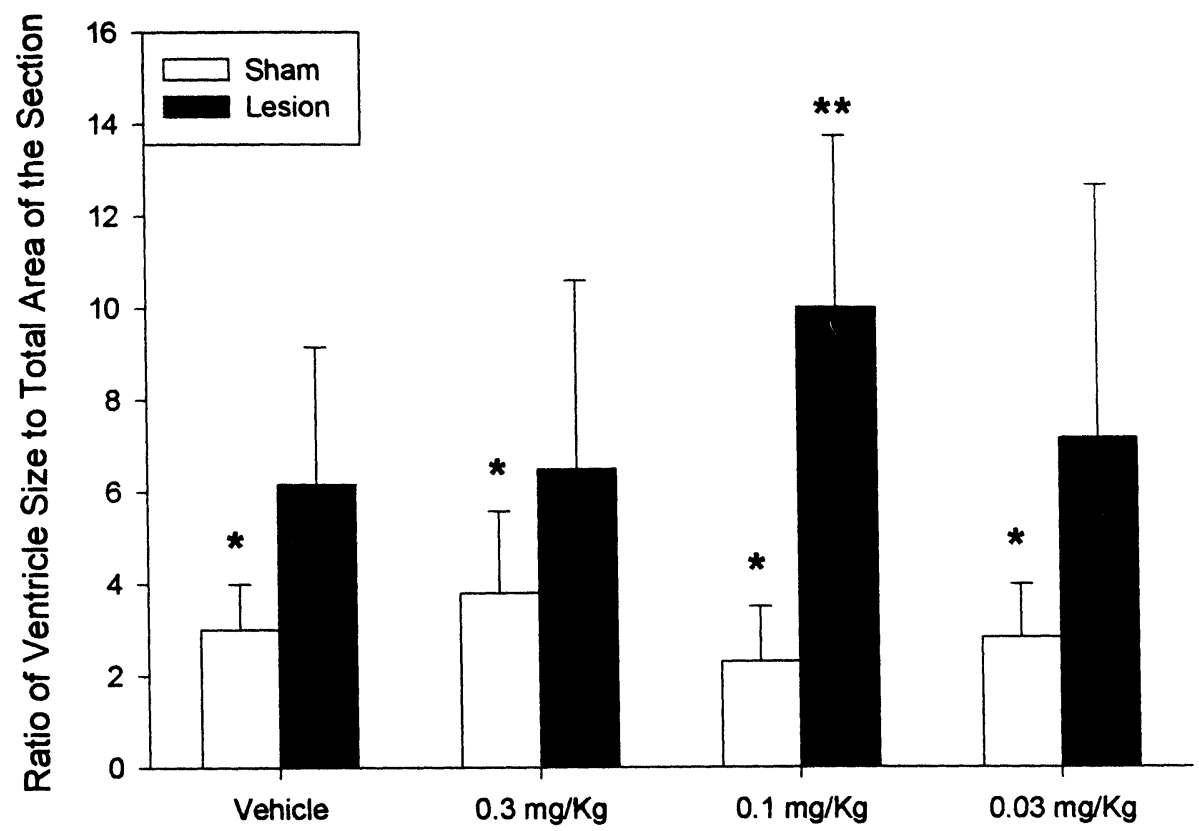

(B)

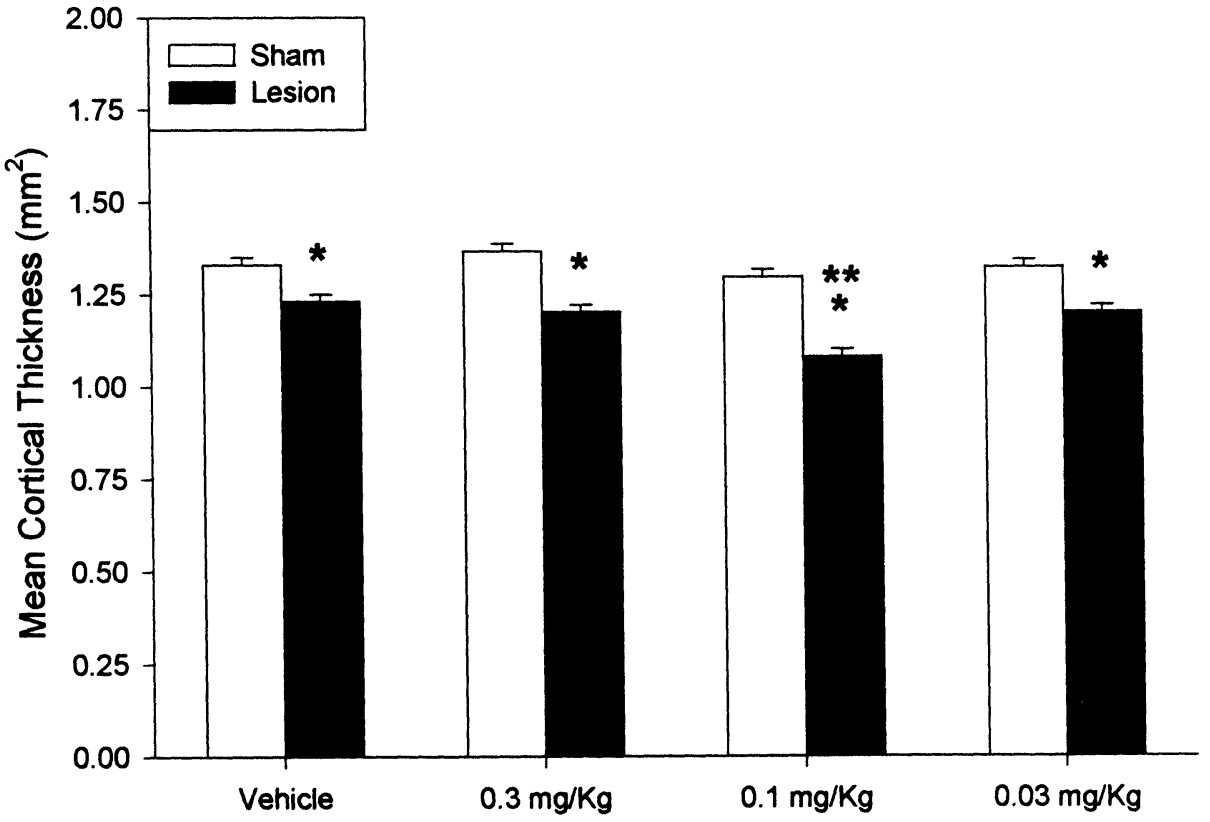

Fig. 4: (a) Ventricle size in gacyclidine-treated and untreated rats. The ventricles of rats treated with $0.1 \mathrm{mg} / \mathrm{kg}$ of gacyclidine were significantly larger than those in untreated animals with similar lesions $(*=p<0.05)$ and larger than those in rats given either 0.3 or $0.03 \mathrm{mg} / \mathrm{kg}$ of gacyclidine $(* *=p<0.05)$. Nonsignificant ventricular enlargement was noted in sham-operated rats given the $0.3 \mathrm{mg} / \mathrm{kg}$ dose of gacyclidine. (b) Cortical thickness in gacyclidine-treated and untreated rats. Rats treated with the $0.1 \mathrm{mg} / \mathrm{kg}$ dose of gacyclidine of showed a decrease in cortical thickness measured at several locations $\left({ }^{* *}=p<0.05\right)$ when compared with contused rats given only vehicle. All animals receiving lesions of the MFC had thinner cortices $(*=p<0.05)$. Sham-operated controls, regardless of dose, showed no change in cortical thickness. 
counterparts $\left[\mathrm{F}_{(1,20)}=15.22, \underline{\mathrm{p}}<0.001\right]$ (Fig. 6a).

\section{Neuronal counts in medial dorsal nucleus of the thalamus (MDN)}

The number of surviving neurons in the MDN declined in all animals with cortical contusions $\left[F_{(1,20)}=41.60, p<0.001\right]$ in comparison with their non-contused counterparts. More surviving neurons were found in rats treated with $0.1 \mathrm{mg} / \mathrm{kg}$ of gacyclidine than in their vehicle treated counterparts $\left[F_{(1,20)}=14.61, \underline{p}<0.001\right]$ (Fig. 6b).

\section{GAFP immunoreactivity}

We have previously shown (Fulop, et. al., 1992) that after medial frontal cortex contusions, a significant increase occurs in the number of GFAP positive astrocytes, both at the site of injury and in areas distal to the lesion. In the present study, we observed a moderate activation of astrocytes in the cortex and septum and heavily stained astrocytes within the striatum at 26 days post-injury. Accordingly, we isolated the analysis to these areas of hyperactivation and found that the number of activated astrocytes was significantly higher $\left(\left[\mathrm{F}_{(1,38)}=179.42, \mathrm{p}<0.001\right]\right.$ in the striatum of contused animals than in the striatum of sham controls Fig. 7a). Although we did not see a significant effect of the drug on astrocyte activation $[\mathrm{F}(1,38)=3.04, \mathrm{p}=0.089]$ nor a lesion $\times$ drug interaction, $\left[F_{(1,38)}=3.15, p=0.084\right]$, the treatment did affect the size of glial cells (Fig. $7 \mathrm{~b}$ ). The cell bodies of astrocytes (Fig. 8a, 8c, $8 \mathrm{e}$ ) in the striatum of animals treated with 0.1 $\mathrm{mg} / \mathrm{kg}$ of gacyclidine were 3 times larger $(0.984 \pm$ $0.05 \mu \mathrm{m}^{2}$ vs. $\left.0.273 \pm 0.025 \mu \mathrm{m}^{2}\right)$ than those of their vehicle-treated counterparts $\left[\mathrm{t}_{(118)}=7.248, \mathrm{p}<0.001\right]$.

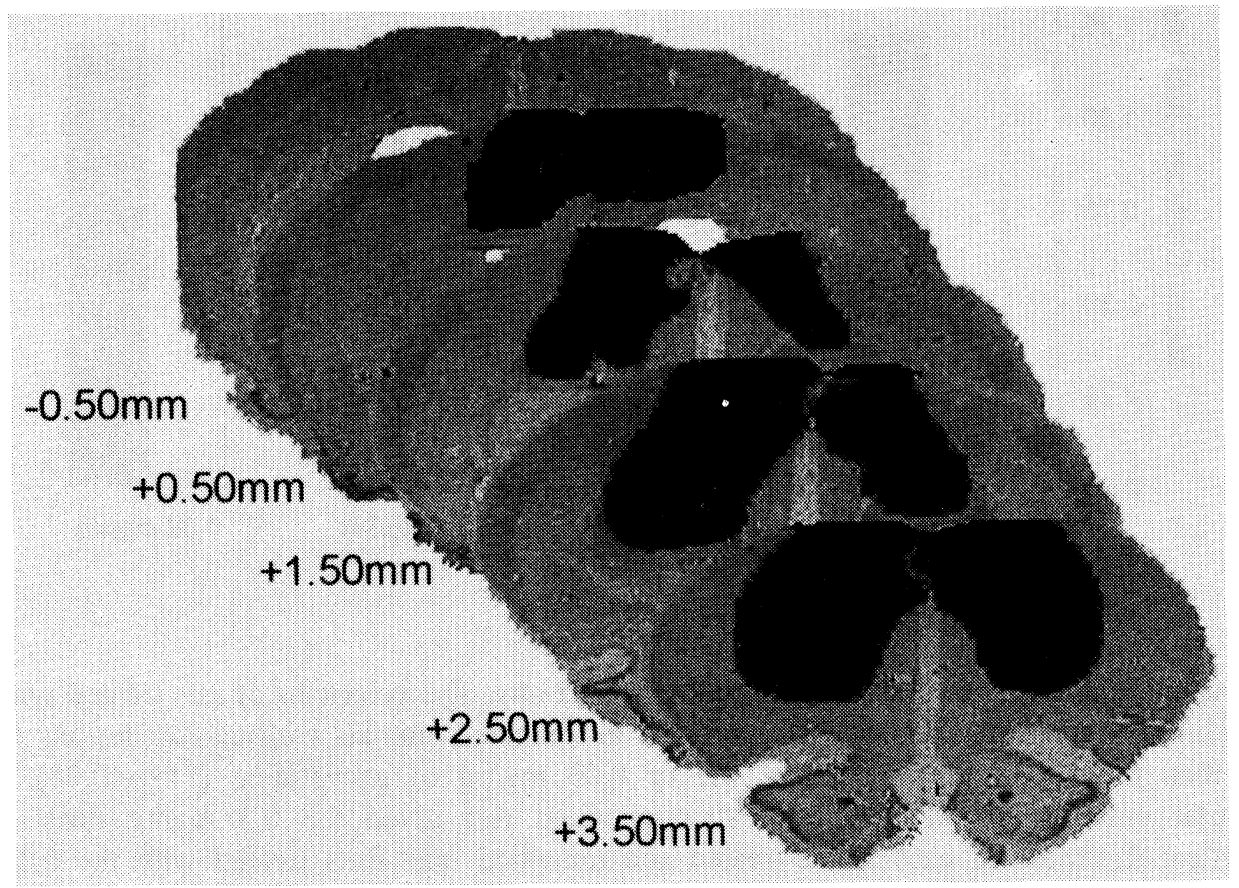

Fig. 5: Lesion reconstruction. A representation of damage induced by the pneumatic contusion device following bilateral contusion to the medial frontal cortex. 
(A)

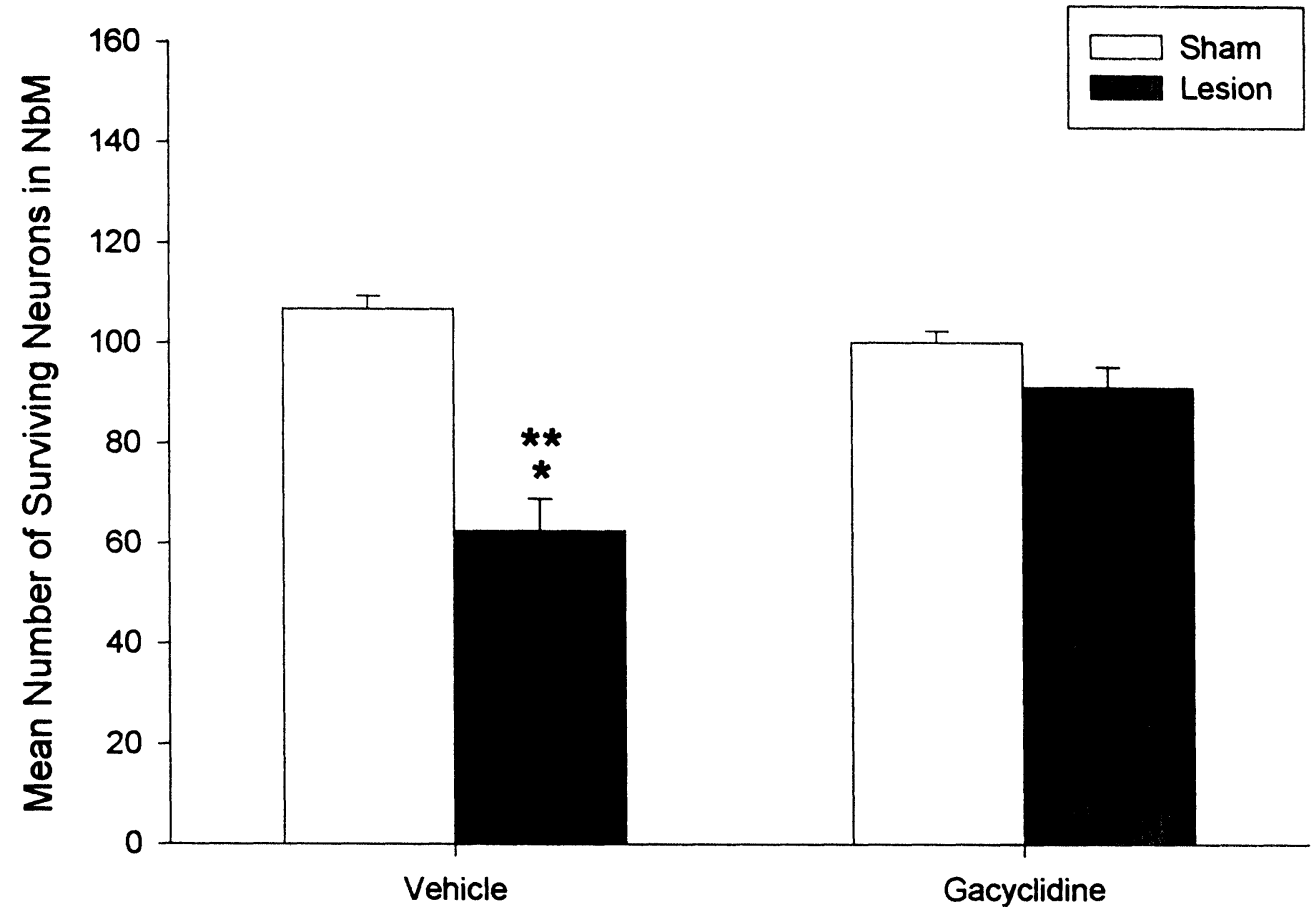

(B)

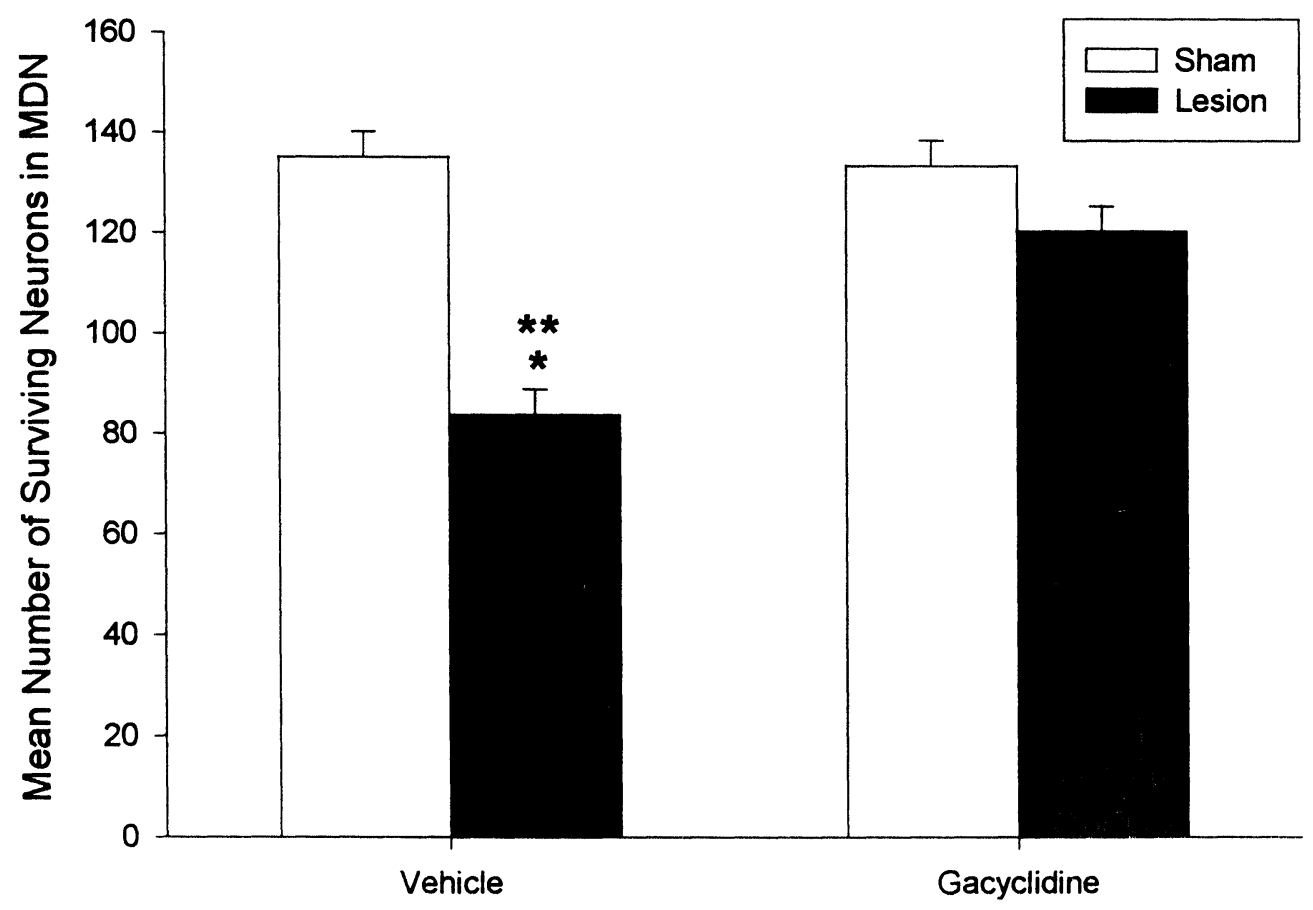

Fig. 6: (a) Number of surviving neurons in the $\mathrm{NBM}\left({ }^{*}=\mathrm{p}<0.05\right)$. Animals treated with $0.1 \mathrm{mg} / \mathrm{kg}$ of gacyclidine had more surviving neurons than their vehicle-treated counterparts $(* *=p<0.05)$. (b) After cortical contusions, a reduction was seen in the number of surviving neurons in the MDN $\left({ }^{*}=\mathrm{p}<0.05\right)$. Animals given $0.1 \mathrm{mg} / \mathrm{kg}$ gacyclidine, however, had more surviving neurons than their vehicle treated counterparts $(* *=p<0.05)$. 


\section{Microglial activation}

The pattern of microglia activation was similar to that of the astrocytes, but in addition to hypertrophy, we also observed a large increase in activated microglia. The number of activated microglia was significantly increased in lesion animals in comparison with those in uninjured controls (Fig. $7 \mathrm{c}$ ), $\left[\mathrm{F}_{(1,32)}=217.62\right.$, $\mathrm{p}<0.001]$. Furthermore, rats treated with gacyclidine had significantly more activated microglia $\left[F_{(1,32)}=19.48, p<0.001\right]$ than did their vehicle treated conspecifics. The microglia (Fig. $8 \mathrm{~b}$, $8 \mathrm{~d}, 8 \mathrm{f})$ in the striatum of rats given $0.1 \mathrm{mg} / \mathrm{kg}$ of gacyclidine were twice as large $\left(0.604 \pm 0.28 \mu \mathrm{m}^{2}\right.$ vs. $0.363 \pm 0.14 \mu \mathrm{m}^{2}$ ) as those in their vehicletreated counterparts $[t(45)=5.05, p<0.001]$ (Fig. 7d).
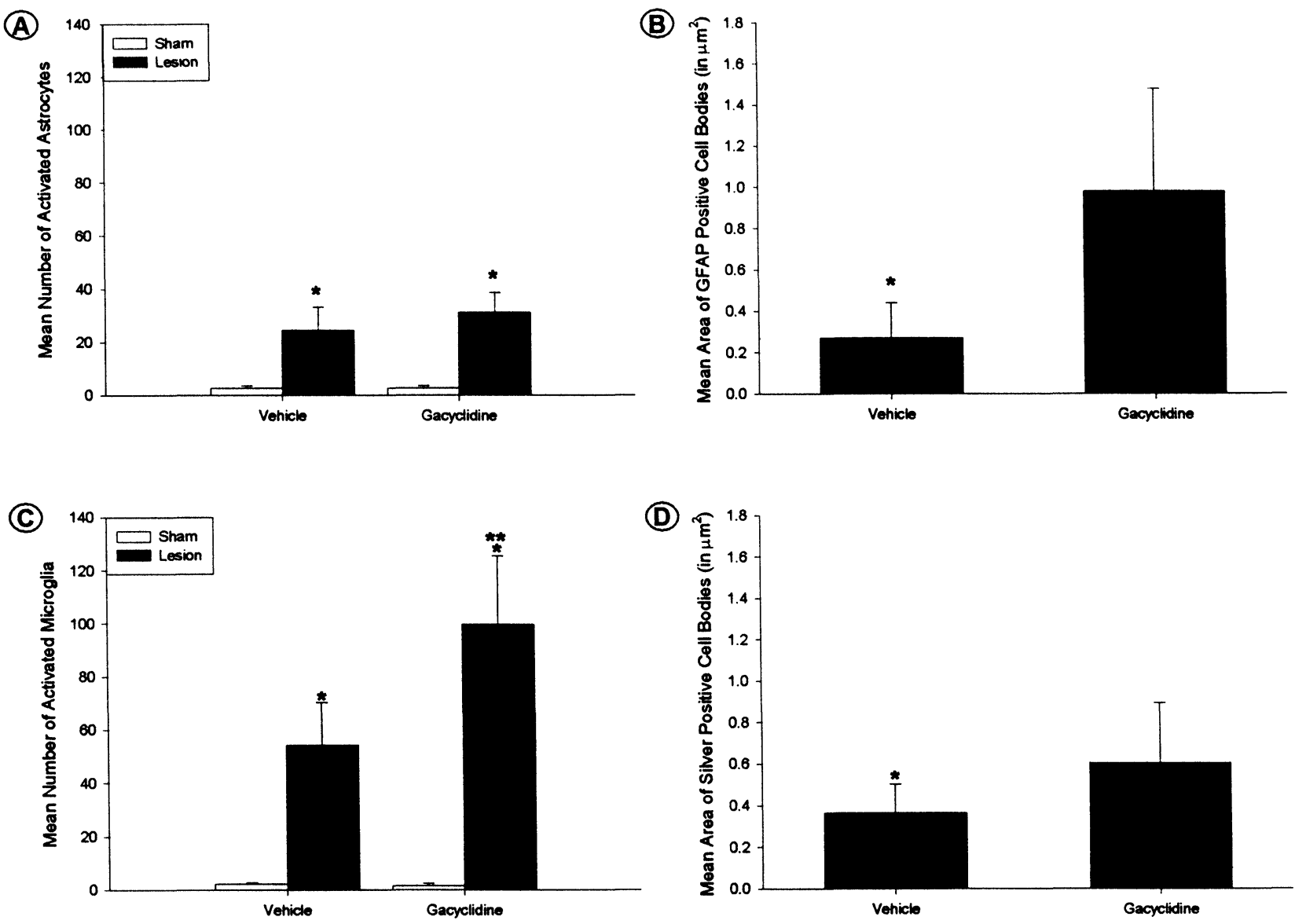

Fig. 7: (a) The number of GFAP positive cells increased $(p<0.05)$, both around the lesion cavity and in sites distal to the locus of injury. In the striatum, rats given $0.1 \mathrm{mg} / \mathrm{kg}$ of gacyclidine showed no increase in the number of activated cells $(p=0.08)$, but $(b)$ did show increases in size $(*=p<0.05)$. At $26 \mathrm{~d}$ post injury in rats receiving 0.1 $\mathrm{mg} / \mathrm{kg}$ gacyclidine, (c) the numbers of activated microglial cells at sites distal to the cavity formation were increased $(*, * *=p<0.05)$, and (d) the size of microglial cells in the striatum was increased $(*=p<0.05)$. 


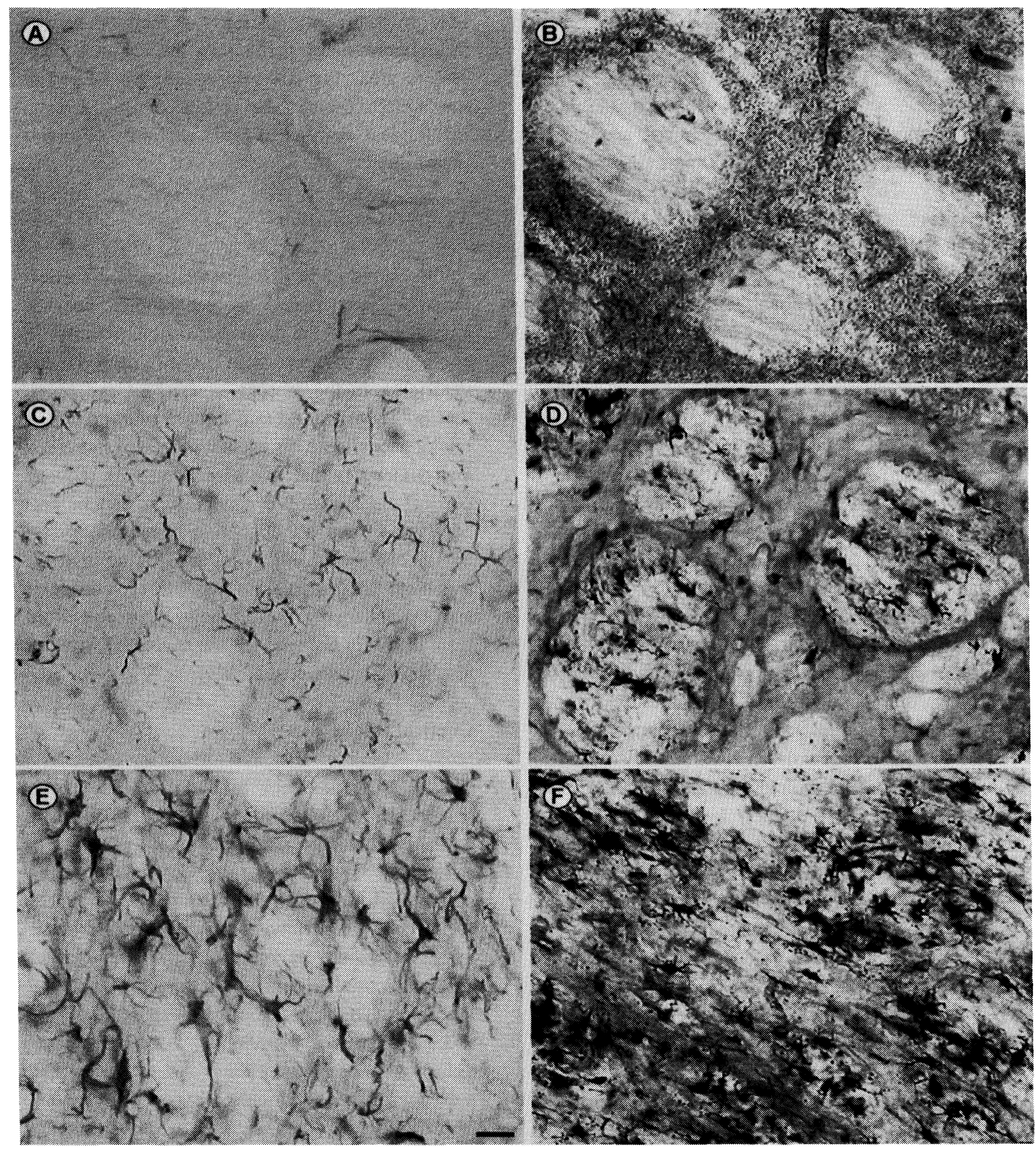

Fig. 8: Microphotographs of astrocytes: (A) Sham-Vehicle $(\times 40),(\mathrm{C})$ Lesion-Vehicle $(\times 40)$, (E) Lesion- $0.1 \mathrm{mg} / \mathrm{kg}$ of gacyclidine $(\times 40)$ and microphotographs of microglia: (B) Sham-Vehicle $(\times 40)$, (D) Lesion-Vehicle $(\times 40),(\mathrm{F})$ Lesion- $0.1 \mathrm{mg} / \mathrm{kg}$ of gacyclidine $(\times 40)$. (Calibration bar $=2 \mathrm{~mm})$ 


\section{DISCUSSION}

Bilateral contusion of the medial frontal cortex is a highly effective and replicable model to study the behavioral, anatomical, and physiological changes that occur after traumatic brain injury. The behavioral deficits caused by this type of brain injury are severe and long lasting (Hoffman, et. al., 1994). Using this injury model to study recovery of function, we have shown that gacyclidine, a novel, noncompetitive NMDA antagonist, improves behavioral and alters anatomic outcomes following medial frontal cortex contusions in adult rats.

All three doses of the drug; $0.01,0.1$, and 0.3 $\mathrm{mg} / \mathrm{kg}$ (i.v.), administered $10 \mathrm{~min}$ after the contusion injury, enhanced the performance of the animals in the water maze. The significantly better performance of rats given the $0.1 \mathrm{mg} / \mathrm{kg}$ dose of gacyclidine than of those given the 0.01 and $0.3 \mathrm{mg} / \mathrm{kg}$ doses reveals a U-shaped or sigmoidal function of the drug's effect; a finding that is not uncommon in such studies. Despite the observation of faster behavioral recovery, we noted that none of the gacyclidine-treated rats reached a level of performance equivalent to that of the intact controls. Gacyclidine also had no influence on the animals' general activity levels during the course of the experiment. The hypoactivity of the contused rats, seen on the first day after surgery, disappeared in all lesion groups by the third postoperative day, when performance was equivalent to that of intact controls.

\section{Lesion reconstruction}

Anatomical reconstruction of the lesions revealed no difference in the extent of damage among the treatment groups. We thus confirmed that all contusions across the groups were approximately the same size and symmetrical. These findings can be interpreted as showing that the beneficial effects of gacyclidine are not associated with sparing of the damaged tissue at the site of injury. We suggest that the compound may work by influencing the maintenance of brain homeostasis, perhaps by sparing neurons in remote areas that are reciprocally connected to the injured tissue. The results of our detailed histological analysis of brain tissue point to this possibility.

\section{Ventricular dilation}

Measures of ventricular dilation and cortical thickness are related to each other because enlargement of the lateral ventricles results in compression of the cortical tissue lying above the ventricles. In the present experiment, we found that both intact and brain-injured rats, given 0.1 $\mathrm{mg} / \mathrm{kg}$ gacyclidine, showed evidence of increased ventricular size that was associated with reduced cortical thickness. We cannot fully explain this observation, and although this phenomenon can be associated with injury-induced tissue loss, we speculate that gacyclidine may affect ventricular size by enhancing the drainage of excess fluid from the brain tissue to the ventricles (O'Brien et al., 1982; Leggate et al., 1988).

\section{Cortical thickness}

The paradoxical effects of improved behavioral outcome, coupled with decreased cortical thickness and neuronal sparing in subcortical areas projecting to the damaged cortex, is difficult to explain, but not completely unheard of. In reviewing the primate literature, Irle (1990) found numerous cases in which larger rather than smaller lesions lead to better functional outcomes. This effect occurs because damaged and dysfunctional neurons create additional disturbances, such as epilepsy for example. The presence of dysfunctional cells can also prevent compensational reorganization from occurring more rapidly (Kass et al., 1983). Here we can only speculate that gacyclidine may have hastened the elimination or suppression of the dysfunctional cells in the damaged cortex, thus leading to enhanced behavioral recovery. Further 
research at the cellular and molecular levels is needed to clarify this issue. Until such work can be completed, caution is warranted in applying this substance as a general treatment for CNS injuries.

\section{Neuronal counts}

Counts of magnocellular neurons in the nucleus basalis revealed that the number of these cells in lesion animals was lower than that in their sham-operated counterparts. In contrast, rats given $0.1 \mathrm{mg} / \mathrm{kg}$ of gacyclidine had more surviving magnocellular neurons in the nucleus basalis than did vehicle-treated lesion controls. We also observed more surviving neuronal cells in the MDN in rats that received $0.1 \mathrm{mg} / \mathrm{kg}$ of gacyclidine.

Our findings can be taken to indicate that gacyclidine increases the survival of neurons in remote subcortical areas of the brain that normally degenerate following medial frontal cortex injury. The effect may be due to the capacity of gacyclidine to prevent glutamate toxicity; a finding that is consistent with the literature for compounds acting on similar receptors and/or having similar mechanisms of action (Jenkins, et al., 1988, McIntosh, et al., 1990, Smith, et al., 1993).

\section{Glial cell activation}

Along with cortical thinning, behavioral improvement and neuronal sparing in the nucleus basalis in gacyclidine-treated brain-damaged rats was paralleled by an increased activation of both astrocytes and microglia. The number of GFAPpositive astrocytes was higher in sham-operated than in all injured groups, both at the site of the injury and in areas distal to the lesions. We also observed that gacyclidine had a profound effect upon the size of the astrocytes and the number of microglia. Astrocytes in the striatum of animals treated with $0.1 \mathrm{mg} / \mathrm{kg}$ of gacyclidine were more than three times larger than astrocytes measured in vehicle-treated rats. In addition to their hypertrophy, activated microglial cells also showed increased proliferation when treated with the $0.1 \mathrm{mg} / \mathrm{kg}$ dose of gacyclidine.

Whereas the cellular hypertrophy observed in both astrocytes and microglia (Fig. 6) could be a sign of pathology (swelling caused by cytotoxic edema), it might also be an indication of the increased synthetic and absorption capacity of the cells (Hanker, G., 1980; Rudge, et al., 1985; Assouline, et al., 1987). Both types of glial cells are reported to be equipped with NMDA receptors (Cull-Candy, 1995; Conti et al., 1996; 1997), although microglial cells are believed to be the primary glial cells capable of activation (or inhibition) by altering their NMDA receptors (Giulian et al., 1994). Activated micro-glial cells, apart from their increased phagocytic capacity, release different types of cytokines, which in turn will activate astrocytes (Waltz, 1989; Wilkin et al., 1991; Balasingam et al., 1994). Activated astrocytes are known to synthesize and release a large variety of neurotrophic factors, which in turn, can increase neuronal survival (Martin, 1992; McGeer \& McGeer, 1995; Vaca \& Wendt, 1992).

\section{CONCLUSIONS}

Our data show that systemically administered gacyclidine has diverse effects in brain-injured rats. First, gacyclidine improved behavioral performance, impaired by the brain trauma. Second, the compound enhanced the survival of neurons in the MDN of the thalamus and of magnocellular neurons in the NBM. The drug also reduced cortical thinning and activated neuroglial cells, leading to both microglial hyperplasia and astrocytic hypertrophy in the striatum. Such a wide range of effects points to the possibility that gacyclidine, apart from its specificity at the PCP site of the NMDA receptor, may have multiple sites of action in the CNS, not all of which may be beneficial.

Several speculative explanations on the 
mechanisms of action of noncompetitive NMDA receptor antagonists were recently published (Haglid et al., 1991; Fox et al., 1996; Nordqvist et al., 1997) including the activation of subcortical structures that are typically depressed by trauma, via the stimulation of dopaminergic neurons. Some of these studies suggest the possibility of a direct, neuroprotective capacity of NMDA antagonists (Sauer et al., 1988), or that they may also work indirectly by activating glial cells (Pearce, 1991; Giulian et. al., 1994). Recently, Obrenovitch \& Urenjak (1997) questioned the validity of the glutamate excitotoxicity hypothesis in the case of traumatic brain injury. The authors argue that the beneficial effect of glutamate antagonists (and blockers of voltage-gated sodium ion channels) in experimental TBI is not due to the role of glutamate in excito-toxicity. Rather, glutamate may act by directly effecting the energy demand, reducing the cells' ability to counterbalance sodium ion influx across the receptor. The authors further argue that glutamate antagonists "may help nervous tissue to cope with increased permeability of the cellular membrane to ions and reduced efficacy of sodium ion extrusion, and thus prevent the decay of transmembrane ionic concentrations gradients" (ibid., p. 684).

The effect of gacyclidine after systemic administration in a complex pathophysiological case, like traumatic brain injury, may be even more general and affect physiological functions outside the CNS. NMDA-receptor antagonists have been shown to have effects on the cardiovascular system (Meyer et al., 1990; Stevens \& Yaks, 1990; Muir \& Lees, 1995; Miller et al., 1996; Maione et al., 1998). Furthermore, these type of drugs influence the body's water balance (Espanol et al., 1994; Kuroda et al., 1994; Sluka et al., 1994); hormone secretion and release (Arslan et al., 1992; Estienne et al., 1996; Pinilla et al., 1996), as well as the respiratory drive and oxygen consumption (Bissonnette et al., 1997; Lu et al., 1997). The observed functional recovery after gacyclidine treatment in our experiments may be due, at least partially, to the above-mentioned effects of NMDA antagonists.

We must emphasize that subsequent research will be needed to characterize fully the systemic and CNS effects of this new NMDA antagonist. The current lack of availability of NMDAreceptor antagonists that are suitable for human use amplifies the interest in gacyclidine as a broad-spectrum, neuroprotective therapeutic agent, but the range of its effects in the CNS still needs careful study and evaluation.

\section{ACKNOWLEDGEMENTS}

The research reported in this publication was supported by a grant from Beaufour Ipsen Pharmaceuticals to DGS. The contents of this paper are solely the responsibility of the authors and do not necessarily represent the official views of IPSEN. We thank Dr. Stuart W. Hoffman for his critical comments during reviewing the manuscript. Authors responsibilities: JSS participated in all phases of the study and had primary responsibility for the conduct of the experiment; ZLF participated in the design of the study, developed and assisted in all of the morphological analyses and assisted in the manuscript preparation; SAL and RSD provided technical support during surgery, histology and behavioral testing; DGS developed the contract, participated in the design of the experiment and in the writing of the manuscript.

\section{REFERENCES}

Arslan M, Pohl CR, Smith MS, Plant TM. Studies of the role of N-methyl-D-aspartate (NMDA) receptor in the hypothalamic control of prolactin secretion. Life Sci 1992; 50: 295-300.

Assouline JG, Bosch P, Lim R, Kim IS, Jensen R, Pantazis NJ. Rat astrocytes and Schwann cells in culture synthesize nerve growth factor-like neurite-promoting factors. Brain Res 1987; 428: 103-118. 
Attella MJ, Hoffman SW, Pilotte MP, Stein DG. Effects of BIM-22015, an analog of ACTH4-10, on functional recovery after frontal cortex injury. Behav Neural Biol 1992; 57: 157-166.

Balasingam V, Tejada-Berges $T$, Wright $E$, Bouckova R, Yong VW. Reactive astrogliosis in the neonatal mouse brain and its modulation by cytokines. J Neurosci 1994; 14: 846-856.

Bissonnette JM, Hohimer AR, and Knopp SJ NonNMDA receptors modulate respiratory drive in fetal sheep. J Psychol (Lond). 1997; 501: 415-423.

Bullock R. Strategies for neuroprotection with glutamate antagonists. Extrapolating from evidence taken from the first stroke and head injury studies. Ann NY Acad Sci 1995; 765: 272-278.

Bullock R, Fujisawa $H$. The role of glutamate antagonists for the treatment of CNS injury. J Neurotrauma 1992; 9: S443-462.

Conti F, DeBiasi S, Minelli A, Melone $M$. Expression of NR1 and NR2A/B subunits of the NMDA receptor in cortical astrocytes. Glia 1996; 17: 254-258.

Conti F, Minelli A, DeBiasi S, Melone M. Neuronal and glial localization of NMDA receptors in the cerebral cortex. Mol Neurobiol 1997; 14: 1-18.

Cull-Candy S. NMDA receptors: do glia hold the key? Curr Biol 1995; 5: 841-843.

Dekker AJA, Connor DJ, Thal L. The role of cholinergic projections from the nucleus basalis in memory. Neurosci Biobehav Rev 1991; 15: 299-317.

Drian MJ, Kamenka JM, Pirat JL, Privat A. Noncompetitive antagonists of N-methyl-Daspartate prevent spontaneous neuronal death in primary cultures of embryonic rat cortex. J Neurosci Res 1991; 29: 133-138.

Espanol MT, Xu Y, Litt L, Chang LH, James TL, Weistein PR, Chan PH. Modulation of edema by dizocilipine, kynurenate, and NBQX in respiring brain slices after exposure to glutamate. Acta Neurochir Suppl (Wien) 1994; 60: 58-61.

Estienne MJ, Harter-Dennis JM, Barb CR, Harstock TG, Campbell RM, Armstrong JD. N-methylD,L-aspartate- induced growth hormone secretion in barrows: possible mechanisms of action. J Animal Sci 1996; 74: 597-602.

Faden AI, Demediuk P, Panter SS, Vink R. The role of excitatory amino acids and NMDA receptors in traumatic brain injury. Science 1989; 244: 798-800.
Fox RM, Jones JE, Atterwill CK. Gliotoxicity in brain reaggregate cultures caused by oxidants and excitatory amino acids can be prevented by alpha-tocopherol and MK-801. Neurotoxicity 1996; 17: 705-710.

Fulop ZL, Lescaudron L, Geller HM, Sutton R, Stein DG. Astrocytes grafted into rat nucleus basalis magnocellularis immediately after ibotenic acid injections fail to survive and have no effect on functional recovery. Int $\mathrm{J}$ Neurosci 1997; 90: 203-222.

Gallyas F. Silver staining of micro- and oligodendroglia by means of physical development. Acta Neuropathol 1970; 16: 35-38.

Golding EM and Vink R. Efficacy of competitive vs noncompetitive blockade of the NMDA channel following traumatic brain injury. Mol Chem Neuropath 1995; 24: 137-150.

Gray R, McNaughton N. Comparison between the behavioural effects of septal and hippocampal lesions: A review. Neurosci Biobehav Rev 1983; 7: 119-188.

Giulian D, Li J, Leara B, Keenen C. Phagocytic microglia release cytokines and cytotoxins that regulate the survival of astrocytes and neurons in culture. Neurochem Intern 1994; 25: 227-233.

Hanker G. Trophic interactions between astroglial cells and hippocampal neurons in culture. Science 1980; 209: 809-810.

Haglid KG, Wang S, Hamberger A, Lehmann A, and Moller CJ Neuronal and glial marker proteins in the evaluation of the protective action of MK 801. J Neurochem 1991; 56: 1957-1961.

Hoffman SW, Fulop Z, Stein DG. Bilateral frontal cortical contusion in rats: behavioral and anatomic consequences. J Neurotrauma 1994; 11: 417-431.

Irle E. An analysis of lesion size, localization and behavioral effects in 283 published studies of cortical and subcortical lesions in old-world monkeys. Brain Res Rev 1990; 15: 181-213.

Janis LS, Hoane MR, Conde D, Fulop Z, Stein DG. Acute ethanol administration reduces the cognitive deficits associated with traumatic brain injury in rats. J Neurotrauma 1998; 15: 105-115.

Jenkins LW, Lyeth BG, Lewelt W, Moszynski K, Dewitt DS, Balster RL, et al. Combined pretrauma scopolamine and phencyclidine attenuate posttraumatic increased sensitivity to delayed secondary ischemia. J Neurotrauma 1988; 5: 275-287. 
Kass JH, Merzenich MM, Killackey HP. The reorganization of somatosensory cortex following peripheral nerve damage in adult and developing mammals. Ann Rev Neurosci 1983; 6: 325-356.

Kolb B, Pittman K, Sutherland RJ, Whishaw IQ. Dissociation of the contributions of the prefrontal cortex and dorsomedial thalamic nucleus to spatially guided behavior in the rat. Behav Brain Res 1982; 6: 365-378.

Kuroda Y, Fujisawa H, Strebel S, Graham DI, Bullock R. Effect of neuroprotective N-methyl$\mathrm{D}$-aspartate antagonists on increased intracranial pressure: studies in the rat acute subdural hematoma model. Neurosurgery 1994; 35: 106-112.

Leggate JR, Baxter P, Minns RA, Steers AJ, Brown JK, Shaw JF, Elton RA. Role of a separate subcutaneous cerebrospinal fluid reservoir in the management of hydrocephalus. $\mathrm{Br} \mathrm{J}$ Neurosurgery $1988 ; 2: 327-337$.

Leonard CM. The prefrontal cortex of the rat. I. Cortical projection of the mediodorsal nucleus. II. Efferent connections. Brain Res1969; 12: 321-343.

Lindner MD, Plone MA, Cain CK, Frydel B, Francis JM, Emerich DF, Sutton RL. Dissociable longterm cognitive deficits after frontal versus sensorimotor cortical contusions. J Neurotrauma 1998; 15: 199-216.

Lu X, Sinha AK, Weiss HR. Effects of excitatory amino acids on cerebral oxygen consumption and blood flow in rat. Neurochem Res 1997; 22: 705-711.

Maione S, Pallotta M, Leyva J, Palazzo E, Rossi F. Effects of diethylentriamine on NMDA-induced increase of blood pressure in rats. Pharmacol Biochem Behav 1998; 59: 233-237.

Martin DL. Synthesis and release of neuroactive substances by glial cells. Glia 1992; 5: 81-94.

Mattson AJ, Levin HS. Frontal lobe dysfunction following closed head injury: A review of the literature. J Nerv Mental Dis 1990; 178: 282291.

McGeer PL, McGeer EG. The inflammatory response system of brain: implications for therapy of Alzheimer and other neurodegenerative diseases. Brain Res Rev 1995; 21: 195-218.

McIntosh TK. Neurochemical sequelae of traumatic brain injury: therapeutic implications. Cerebrovas Brain Metab Rev 1994; 6: 109-162.

McIntosh TK, Vink R, Soares H, Hayes R, Simon R. Effect of noncompetitive blockade of N-methylD-aspartate receptors on the neurochemical sequelae of experimental brain injury. J Neurochem 1990; 55: 1170-1179.

Meyer FB, Anderson RE, Fridrich PF. MK-801 attenuates capillary bed compression and hypoperfusion following incomplete focal cerebral ischemia. J Cerebral Blood Flow Metab 1990; 10: 895-902.

Miller RD, Monsul NT, Vender JR, Lehmann JC. NMDA-and endothelin-1-induced increases in blood-brain barrier permeability quantitated with Lucifer yellow. J Neurol Sci 1996; 136: 37-40.

Morris RGM. Spatial localization does not require the presence of local cues. Learn Mot 1981; 12 : 284-287.

Muir KW and Lees KR. Clinical experience with excitatory amino acid antagonist drugs. Stroke 1995; 26: 503-513.

Murphy S, Pearce B. Functional receptors for neurotransmitters on astroglial cells. Neuroscience $1987 ; 22$ : 381-394.

Myseros JS, Bullock R. The rationale for glutamate antagonists in the treatment of traumatic brain injury. Ann NY Acad Sci 1995; 765: 262-271.

Nordqvist AC, Holmin S, Nilsson M, Mathiesen T, Schalling $M$. MK-801 inhibits the cortical increase in IGF-1, IGFBP-2 and IGFBP-4 expression following trauma. Neuroreport 1997; 8: $455-460$.

Obrenovitch TP, Urenjak J. Is high extracellular glutamate the key to excitotoxicity in traumatic brain injury? J Neurotrauma 1997; 14: 677-698.

O'Brien MD, Haggith JW, Appleton D. Cerebrospinal fluid dynamics in Dementia. Exp Brain Res (Suppl) 1982; 5: 196-200.

Okiyama K, Smith DH, White WF, Richter K, McIntosh TK. Effects of the novel NMDA antagonists CP-98,113, CP-101,581 and CP-101,606 on cognitive function and regional cerebral edema following experimental brain injury in the rat. $\mathrm{J}$ Neurotrauma 1997; 14: 211-222.

Olney JW, Labruyere J, Wang G, Sesma MA, Wozniak DF, Rice MT. NMDA antagonist neurotoxicity: mechanism and protection. Science 1991; 254: 1515-1518.

Panter SS. Faden AI. Pretreatment with NMDA antagonists limits release of excitatory amino acids following traumatic brain injury. Neurosci Lett 1992; 136: 165-168.

Paxinos G, Watson C. The Rat Brain, New YorkSydney, Academic Press, 1986.

Pearce B. Glia as targets for neuroactive substances. Ann NY Acad Sci 1991; 633: 432-433.

Pinilla L, Tena-Sempere M, Gonzalez D, Aguilar E. 
Positive role of non-N-methyl-D-aspartate receptors in the control of growth hormone secretion in male rats. J Endocrinol Invest 1996; 19: 353-358.

Roof RL, Duvdevani R, Braswell L, Stein DG. Progesterone facilitates cognitive recovery and reduces secondary neuronal loss caused by cortical contusion injury in male rats. Exp Neurol 1994; 129: 64-69.

Rudge JS, Manthorpe M, Varon S. The output of neuronotrophic and neurite-promoting agents from rat brain astroglial cells: a microculture method for screening potential regulatory molecules. Brain Res 1985; 351: 161-172.

Sauer D, Nuglisch J, Rossberg C, Mennel H-D, Beck T, Bielenberg GW, Kreiglstein J Phencyclidine reduces postischemic neuronal necrosis in rat hippocampus without changing blood flow. Neurosci Lett 1988; 91: 327-332.

Sluka KA, Jordan HH, Westlund KN. Reduction in joint swelling and hyperalgesia following posttreatment with a non-NMDA glutamate receptor antagonist. Pain 1994; 59: 95-100.

Smith DH, Okiyama K, Gennarelli TA, McIntosh TK. Magnesium and ketamine attenuate cognitive dysfunction following experimental brain injury. Neurosci Lett 1993; 157: 211-214.
Stein DG, Halks-Miller M, Hoffman SW. Intracerebral administration of alpha-tocopherolcontaining liposomes facilitates behavioral recovery in rats with bilateral lesions of the frontal cortex. J Neurotrauma 1991; 8: 281-292.

Stevens MK, Yaksh TL. Systematic studies on the effects of NMDA receptor antagonist MK-801 on cerebral blood flow and responsivity, EEG, and blood-brain barrier following complete reversible cerebral ischemia. $\mathrm{J}$ Cerebral Blood Flow Metab 1990; 10: 77-88.

Vaca K, Wendt E. Divergent effects of astroglial and microglial secretions on neuron growth and survival. Exp Neurol 1992; 118: 62-72.

Walz W. Role of glial cells in the regulation of the brain ion microenvironment. Prog Neurobio 1989; 33: 309-333.

Watson RE, Wiegand SJ, Clough RW, Hoffman GE. Use of cryoprotectant to maintain long-term peptide immunoreactivity and tissue morphology. Peptides 1986; 7: 155-159.

Wilkin GP, Marriott DR, Cholewinski AJ, Wood JN, Taylor GW, Stephens GJ, Djamgoz MB. Receptor activation and its biochemical consequences in astrocytes. Ann NY Acad Sci $1991 ; 633: 475-488$. 

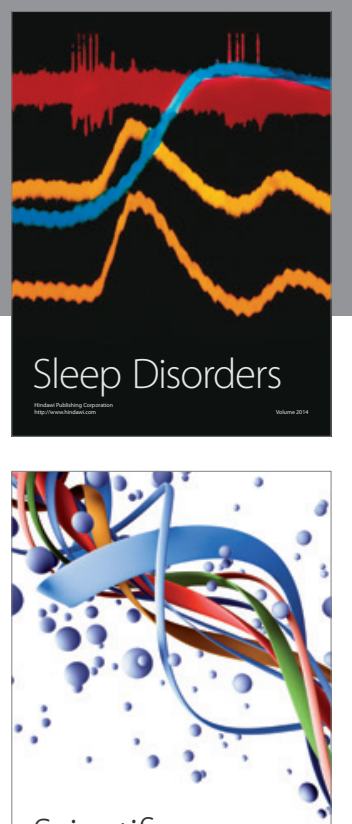

Scientifica
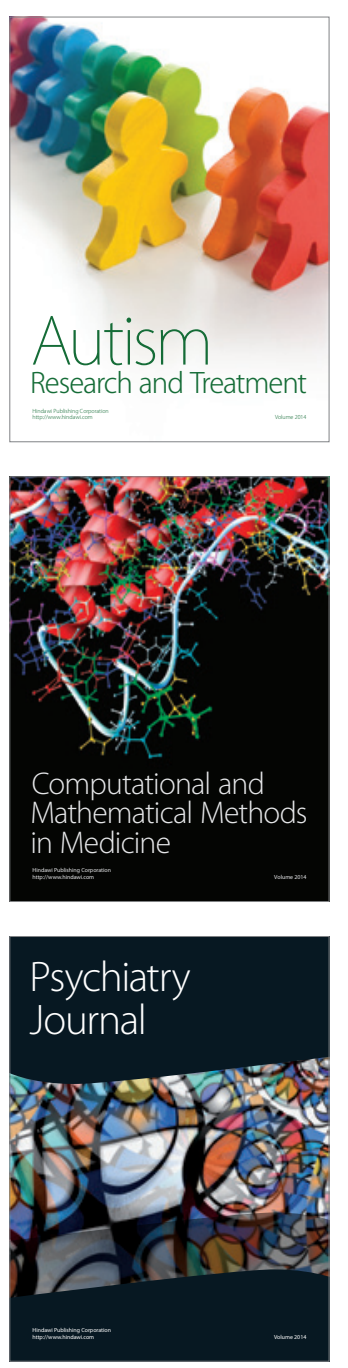
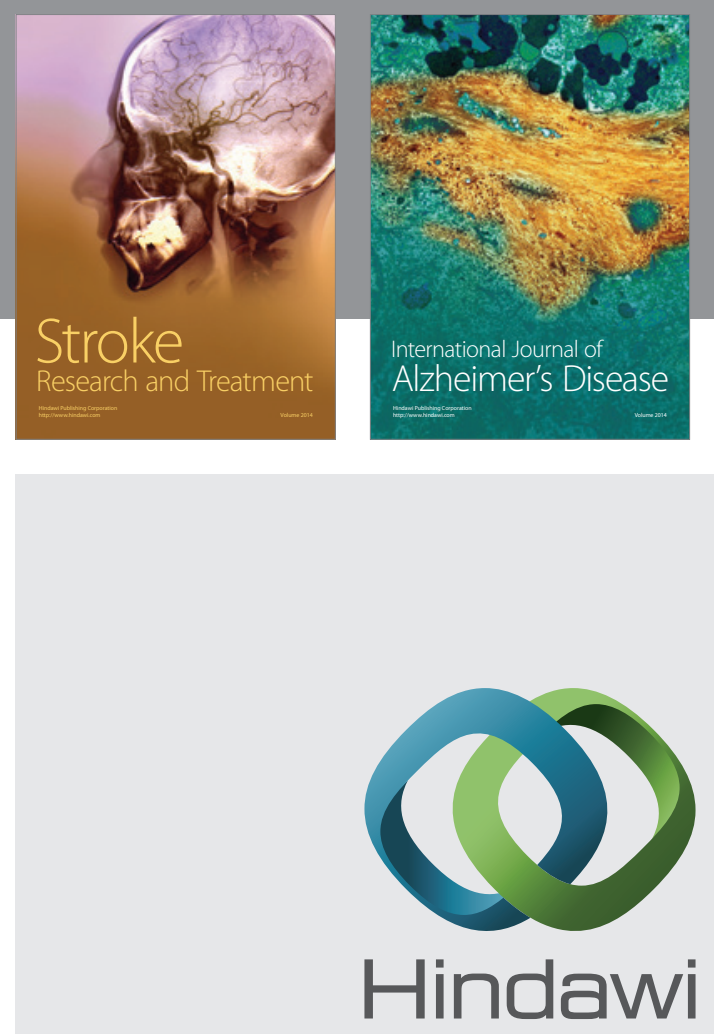

Submit your manuscripts at

http://www.hindawi.com
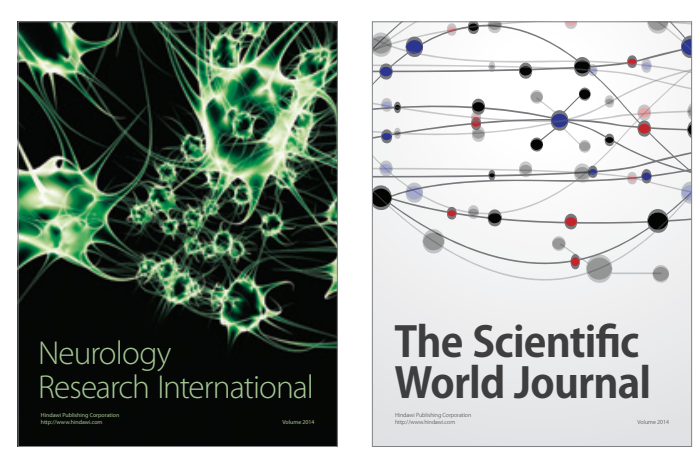

The Scientific World Journal

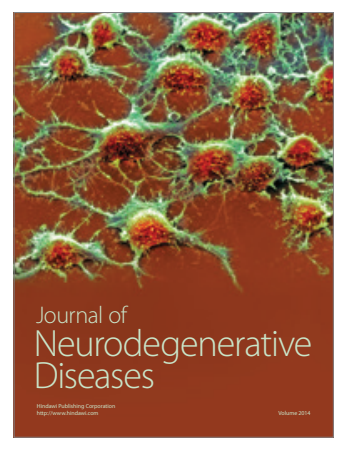

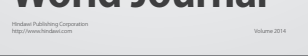

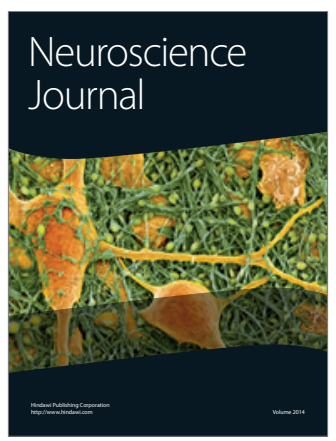

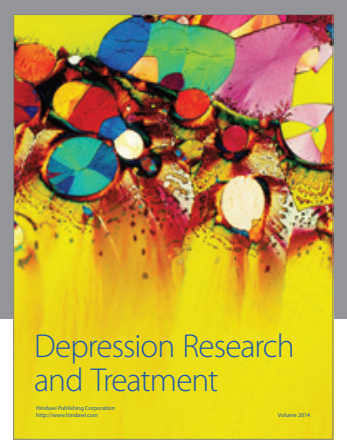
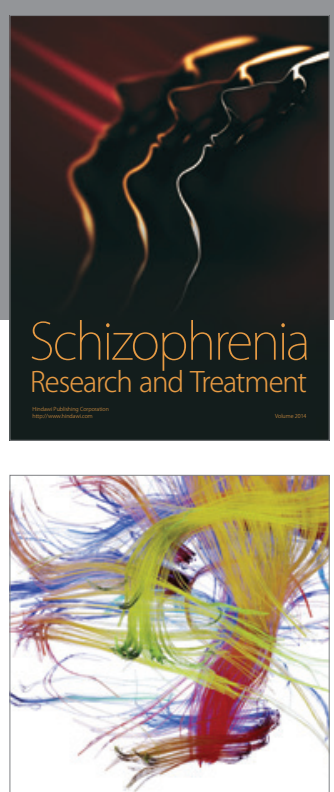

Brain Science

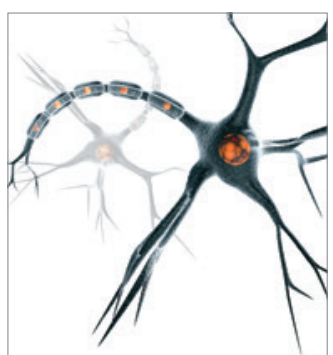

Neural Plasticity
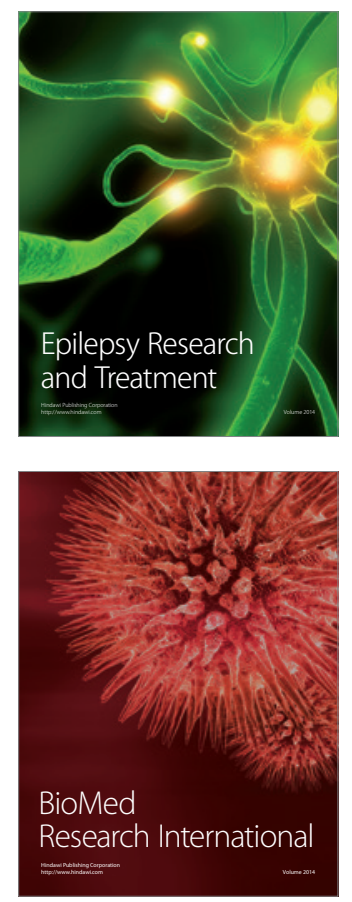

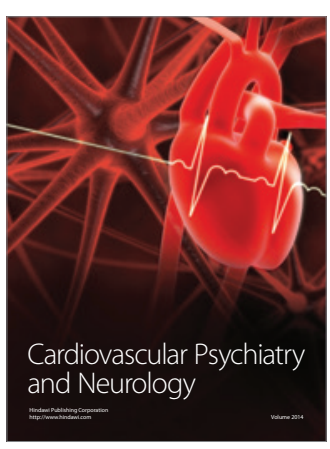

Parkinson's

Disease
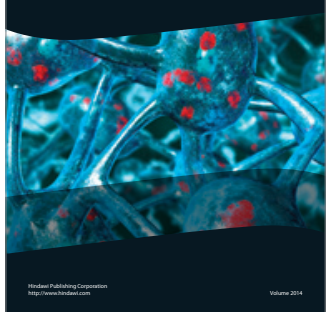